\title{
Social Health and Quality of Life in Health Workers in Qorveh and
}

\author{
Dehgolan, 2019
}

\author{
Marzieh Maleki ${ }^{1}$, Sara Janmohammadi ${ }^{2}$, Zahra Ahmadi ${ }^{3}$, Hamid Haghani ${ }^{4}$
}

\begin{abstract}
Background \& Aims: Health workers are the most fundamental elements of the health system whose mission is to improve the health of the rural community. Assessing and measuring the level of health is one of the important health issues. Health is a broad concept with multiple dimensions including physical, mental, and social health. Social health is a concept that has become increasingly important in scientific, policy, and executive circles. Social health emphasizes aspects of health related to a person's relationship with other people or the communities in which he lives. One of the factors affecting social health is quality of life. Quality of life is a multidimensional concept affected by many important factors such as physical and mental conditions. Assessing the quality of life is important in order to determine physical, mental, and social performance. These dimensions can be discussed independently, but there is a correlation between them. Certainly, the development of health promotion programs in the community, regardless of the social and cultural context of the community in question leads to inefficient solutions. Despite the importance of health workers' work, their high volume of work, and pathological consequences, few studies are conducted on the qualitative and social fields of health workers. As a result, it is necessary to pay attention to their physical, mental, and social health and quality of life. Achieving goals in the field of health requires preventing death, reducing disability, improving the quality of life, and efficient workforce. Since health workers are at the forefront of health care centers, it is necessary to have good social health and quality of life to provide services to villagers. Therefore, this study was conducted to determine the social health and quality of life in health workers in Qorveh and Dehgolan in 2019.

Materials \& Methods: This study was conducted to evaluate the social health and quality of life of health workers in Qorveh and Dehgolan cities affiliated to Kurdistan University of Medical Sciences. This was a descriptive cross-sectional study and included 198 health workers working in health centers in Qorveh and Dehgolan cities. Among them, 87 were working in 42 health centers of Dehgolan and 111 in 58 health centers of Qorveh. Samples were selected by census sampling method. After obtaining approval from the Research Ethics Committee and receiving a letter of introduction from Iran University of Medical Sciences and submitting it to Kurdistan University of Medical Sciences, the researcher obtained permission to participate in the research. In order to observe ethical considerations, the researcher first explained the objectives and method of the study to the officials of Qorveh and Dehgolan health centers, and in collaboration with them attended the workshops where the researcher attended as a lecturer and after obtaining informed consent, the researched distributed demographic information form, Social Health Questionnaire, and SF-36 Quality of Life Questionnaire among health workers to complete in 10 days and deliver to Qorveh health workers, and then to Dehgolan Welfare Training Center, and subsequently to Dehgolan Health Center. The researcher thanked the health workers and collected the information of the health workers who were absent during the workshops hold in the health centers. After collecting information which lasted for 3 months, the data were analyzed using SPSS software version 16.

Results: The findings of the present study showed that most of the health workers participating in this study were women, their average age was 37 years, the majority were married, and officially employed, and had a diploma degree. Most of them assessed their economic situation as moderate, owned a house, and had no underlying

\footnotetext{
1. MS., Community Health Education, School of Nursing and Midwifery, Iran University of Medical Sciences, Tehran, Iran

2. Department of Community Health Nursing, School of Nursing and Midwifery, Iran University of Medical Sciences, Tehran, Iran (Corresponding author) Tel: $09122763572 \quad$ Email: Janmohammadi.s@iums.ac.ir

3. Department of Community Health Nursing, School of Nursing and Midwifery, Iran University of Medical Sciences, Tehran, Iran

4. Department of Biostatistics, School of Health, Iran University of Medical Sciences, Tehran, Iran
} 
diseases. The total score of social health was $69.28 \pm 7.6$ which indicates the average social health in health workers. The highest and lowest mean scores obtained among the dimensions of social health were social cohesion with an average of $4.09 \pm 20.67$ and social acceptance with an average of $2.96 \pm 0.64$, respectively. The total score of quality of life of health workers was $63.30 \pm 20.87$, which indicates their average quality of life. Quality of life was the highest in the dimension of physical function with an average of $73.35 \pm 29.74$, and was the lowest in the dimension of general health with an average of $57.82 \pm 21.74$. Also, the physical health dimension with an average of $63.85 \pm 24.58$ was higher than the mental health dimension with an average of $62.75 \pm 21.29$. The only variable that had a statistically significant relationship with the social health of health workers was housing status $(\mathrm{p}=$ 0.005). Tukey's multiple comparison showed that the average score of social health obtained for health workers with a private home was significantly higher than those with a rental house $(\mathrm{p}=0.005)$, and the difference was not significant in other cases. But all demographic variables of health workers had a statistically significant relationship with quality of life. The results showed that the quality of life in male health workers compared to the females $(\mathrm{p}=0.012)$, health workers with diploma degree compared to health workers with secondary education ( $\mathrm{p}<0.001)$, single health workers compared to married ones ( $\mathrm{<}<0.001)$, and health workers who had no history of disease was higher $(\mathrm{p}<0.001)$. Age was another variable that had a statistically significant relationship with quality of life ( $p<0.001)$. Quality of life in health workers with formal employment was significantly lower than corporate health workers $(p<0.001)$ and also contracted ones $(p=0.007)$, and this difference was not significant at other levels. Quality of life in health workers with more than 20 years of experience was significantly lower than health workers with $10-19$ years of experience $(\mathrm{p}<0.001)$ and also less than 10 years of experience $(\mathrm{p}$ $<0.001$ ). The quality of life in health workers with poor economic status was significantly lower than those with average economic status $(\mathrm{p}=0.04)$ and this difference was not significant at other levels. Housing status was another variable that had a statistically significant relationship with quality of life $(p=0.009)$. Also, the mean score of quality of life obtained for health workers with a private home was significantly higher than those with a rental house $(\mathrm{p}=0.018)$ and in other cases this difference was not significant.

Conclusion: The present study showed that the social health of health workers was average and higher than the mean score of 60. The highest and lowest scores obtained in the dimensions of social health were social cohesion and social acceptance, respectively. Also, the quality of life of health workers was moderate. Health workers obtained the highest score in the physical function dimension and the lowest score in the general health dimension. The mean score in the physical dimension was higher than the mental health dimension. The study on the effect of demographic variables showed that the only variable with a statistically significant relationship with social health was housing status and the difference was not significant for the other cases. All demographic variables of health workers had a statistically significant relationship with quality of life. Variables of quality of life and social health are dynamic concepts that change over time. Examining and measuring this concept depicts the status of human development in society, so continuous monitoring of quality of life and social health is essential. The health system will have the desired efficiency when the problems and needs of its employees are taken into account in its design and management. The results of this study highlight the importance of implementing health education and health promotion interventions in the field of social health and quality of life among employees.

Keywords: Social Health, Quality of Life, Health Workers

Conflict of Interest: No

How to Cite: Maleki M, Janmohammadi S, Ahmadi Z, Haghani H. Social Health and Quality of Life in Health Workers in Qorveh and Dehgolan, 2019. Iran Journal of Nursing. 2021; 33(128):40-53.

Received: 9 Nov 2020

Accepted: 8 Feb 2021 


\title{
سلامت اجتماعى و كيفيت زندگى در بهورزان شهر ستانهاى قروه و دهكلان
}

\author{
مرضيه مالكى'، سارا جان محمدى '، زهرا احمدى 'ّ، حميد حقانىع
}

جكيده

زمينه و هدف: سلامت اجتماعى، مفهومى است كه بهطور فزاينداى در محافل علمى و سياست كذارى و اجرائى اهميت بيدا كرده است. از عوامل مؤثر

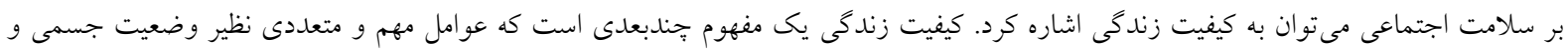

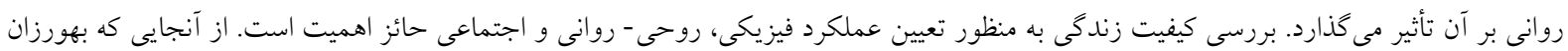

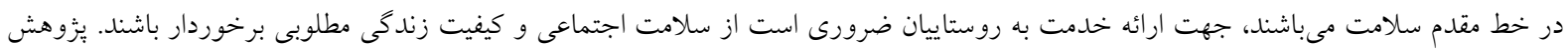

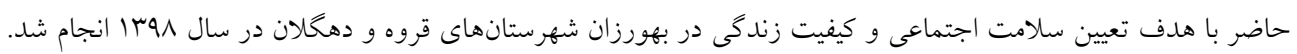

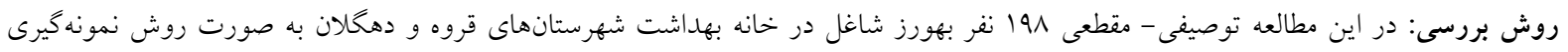

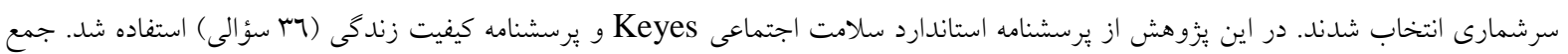

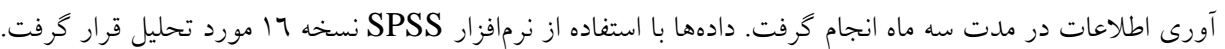

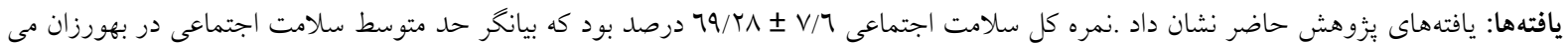

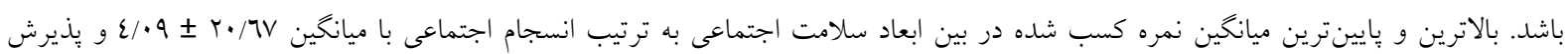

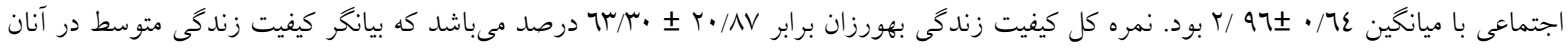

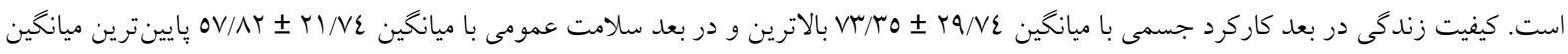
نتيجه كيرى كلى: ئزوهش حاضر نشان داد سلامت اجتماعى بهورزان از ميانه نمره ابزار يعنى ل7 بالاتر و در حد متوسط بود. همجينين كيفيت زندكى

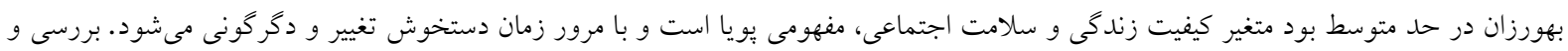

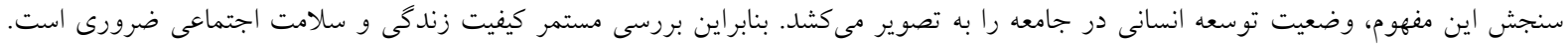

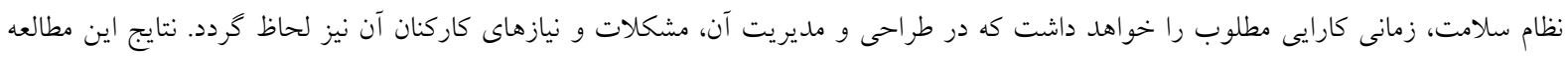

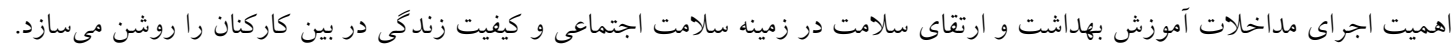

كليد وازهها: سلامت اجتماعى، كيفيت زندگى، بهورزان

تعارض منافع: ندارد

تاريخ دريافت: 99/N/19

تاريخ بذيرش: • 99/11/r

شماره تماس:

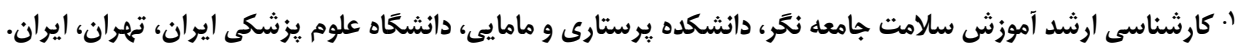

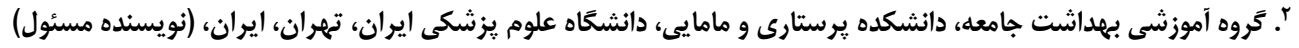




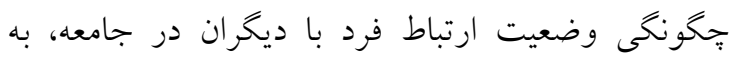

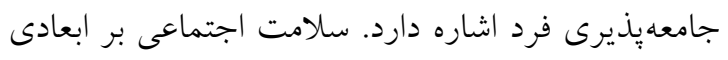

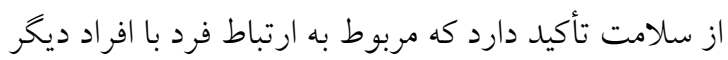

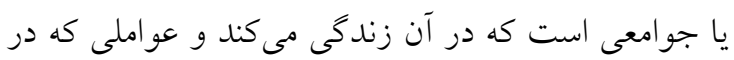

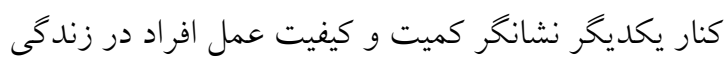
اجتماعى است. اين عوامل عبارتاند از: شكوفايى، انطباق،

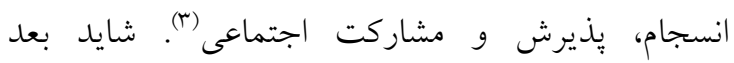
اجتماعى سلامت بيجيدهدرين و در عين حال بحث

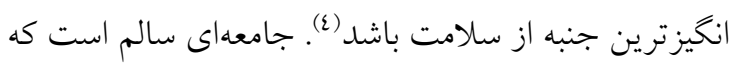

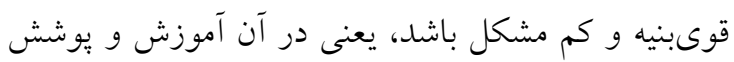
بيمه و رشد جمعيت، فقر، خشونت، و بيكارى كم باشد (0). با توجه به نقش عمدهاى كه سلامت اجتماعى در همه ابعاد زندكى افراد دارد، به نظر مىرسد زمان آن فرا رسيده است كه در نظام بهداشت و درمان كشور به اين موضوع مهم و حياتى برداخته شود. سازمان بهاشت جهانى نيز تأكيد نموده است كه با وجود اهميت خدمات درمانى در تشخيص و بهبود بيمارىهاى جدى، شرايط اقتصادى و اجتماعى كه انسانها را بيمار مى كند و احتياج به درمان را ضرورى مى سازد، اهميت بيشترى براى بهلداشت همه مردم

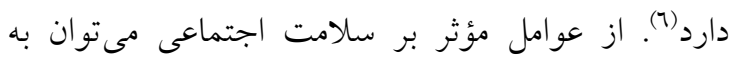
كيفيت زندكى اشاره كرد. تعريف هاى ارائه شده از كيفيت زندگى كه در جهت استفاده در مراقبتهاى بهداشتى و درمانى مفيد هستند را مىتوان به ينج حوزه تقسيم كرد كه شامل زندكى عادى، خوشحالى، دستيابى به اهداف فردى، مفيد بودن به حال جامعه و ميزان ظرفيت طبيعى است. Keyes و معتقدند كه كيفيت زند Shapiro شخصى فرد را نمى توان بدون توجه به معيارهاى اجتماعى ارزيابى كرد و عملكرد خوب در زندگى جيزى بيش از سلامت جسمى، عاطفى و روانى است و عملكرد اجتماعى افراد را نيز در برمى گيرد. آنها مفهوم سلامت اجتماعى را به معنى ارزيابى فرد از عملكردش در برابر اجتماع بيان مى كنند (v). بررسى كيفيت زندكى به منظور تعيين عملكرد فيزيكى، روانى و اجتماعى حائز اهميت است. سازمان جهانى بهداشت كيفيت زندكى را ارزيابى و ادراى افراد از

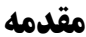
امروزه از سلامت به عنوان محور توسعه يايدار نام برده مىشود و به همين دليل يكى از وظايف حاكميتى دولتها

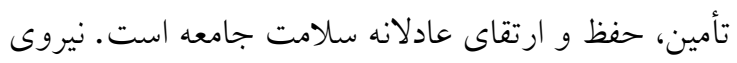
كار، بازوى كارآمـــ و مولـد هـر كـشور بـوده و نظـام مـديريتى از توانمندىهاى ذهنى، جسمى و روانى آنها براى برآوردن نيازهاى توسعه و بيشرفت جامعه بهره

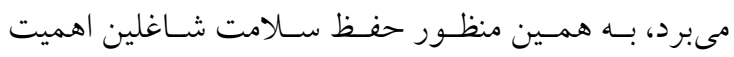
ويزهاى داشته و يكى از شاخصىهاى مهم توسعهيافتكى محسوب مىشود. سلامت شامل برخوردارى فرد از

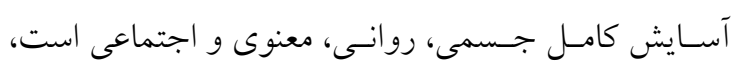
بنابراين در سلامت كاركنان دولت به خصوص بهورزان بايد سعى گردد به تمامى اين ابعاد يرداخته شود. بعد سلامت اجتماعى يكى از مهمترين و بيجيديدترين ابعاد سلامت است كه اثرات بيشخيرانه بر روى دو بعد جسمى ليشى و روانى دارد. امروزه سلامت اجتماعى در كنار سالات جسمى، روانى و معنوى به عنوان يكى از ابعاد سلامت،

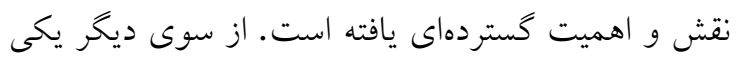
از جنبه هاى مهم و اساسى زندكى هر شخص كه همواره در بيى دست يافتن به آن مىباشد، كيفيت زندگى است كه تمام ابعاد زندگى از جمله سلامت را شامل مى شود. كيفيت زندگى، مفهومى يويا است و با مرور زمان دستخوش تغيير و دگركونى مىشود. بررسى و سنجش اين مفهوم، وضعيت توسعه انسانى در جامعه را به تصوير مى كشد بنابراين بررسى مستمر كيفيت زندگى ضرورى است (1). امروزه سلامت اجتماعى در كنار سلامت جسمى، روانى و معنوى برى نقش و اهميت كستردهاى يافته است، به كونهاى كه ديخر

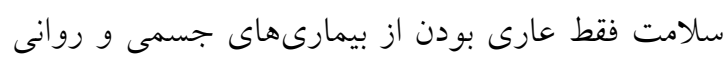

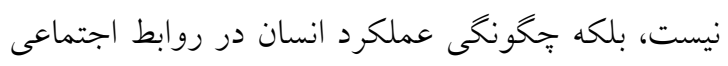

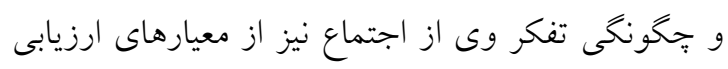
سلامت فرد در سطح كلان جامعه به شمار مىرود. سازمان جهانى بهداشت، سلامتى را توانايى كامل براى ايفاى نقش هاى جسمى، روانى و اجتماعى معرفى مى كند و سلامتى را، تنها نبود بيمارى نمىداند(r). سلامت اجتماعى به له 
نكرفته است كه لزوم انجام اين مطالعه را نشان مىدهد.

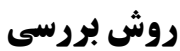

اين مطالعه از نوع توصيفى مىباشد كه در بإييز سال رهبا در سطح خانهاى بهاشت شهرستان قروه و دهخلان استان

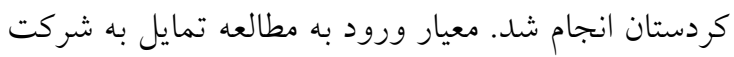
در يزوهش و شاغل بودن در زمان انجام مطالعه بود. با لمان توجه به اين كه تمام بهورزان شاغل در خانههاى بهاشت

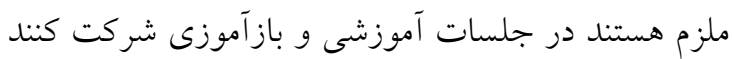
و يزّوهشكر به عنوان مدرس در اين جلسات حضور دارد، هرئ يُزوهشكر به منظور جمع آورى دادهها با مسئولين مراكز

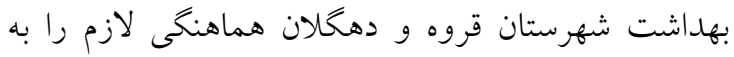

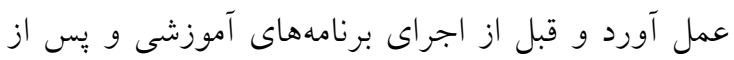

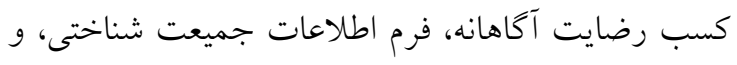

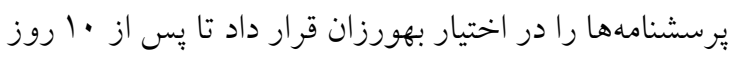

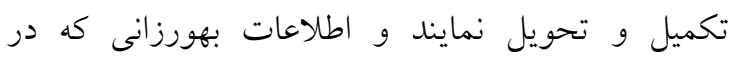

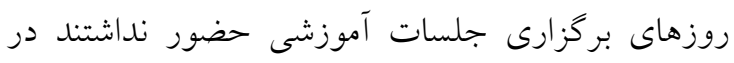
خانه بهداشت جمع آورى شد. تمام بهورزان كه شامل 191 نفر بودند در يُزوهش شركت نمودند.

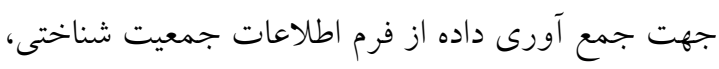
يرسشنامه سلامت اجتماعى Keyes و يرسشنامه كيفيت

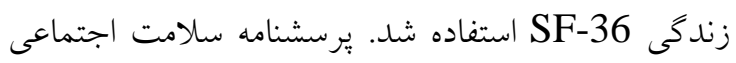
توسط Keyes در بنياد علمى Mac Arthur ايالات

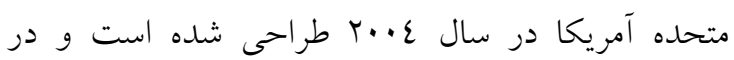

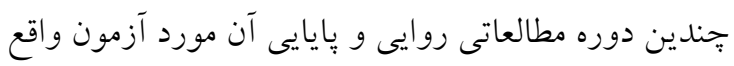

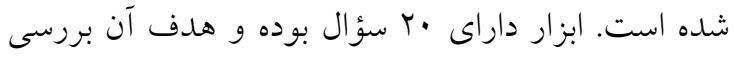

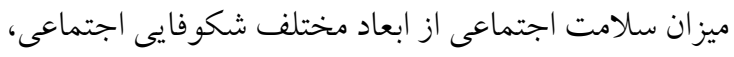
همبستخى اجتماعى، انسجام اجتماعى، يذيرش اجتماعى و

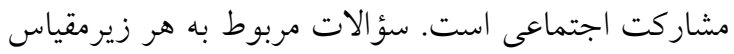
شامل موارد زير است: شكوفايى اجتماعى (سؤالات ع-1)،

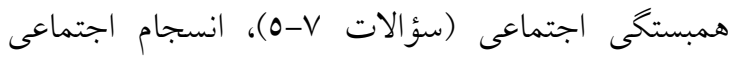

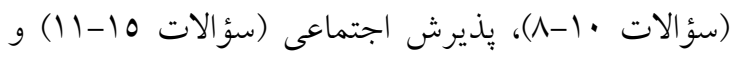

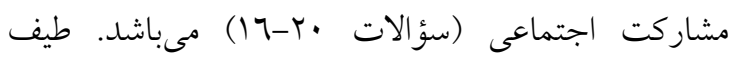
باسخخُويى آن از نوع ليكرت بوده كه امتيازات شامل، كاملاً
وضعيت زندكى خويش، تحت تأثير نظام فرهنكى و

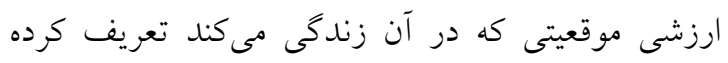

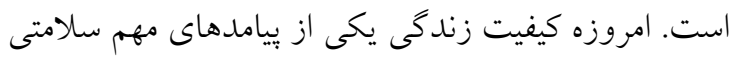

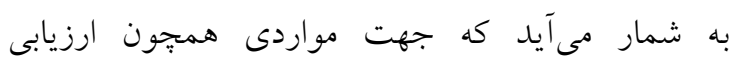

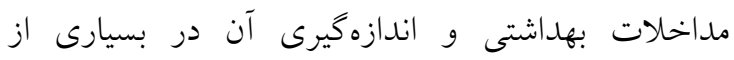
يزّوهش هاى سلامتى ضرورى است (م). بهورز بنيادىترين ركن نظام سلامت است. حوزه فعاليتهاى آنها فقط در روستاهاى اصلى كه داراى خانه

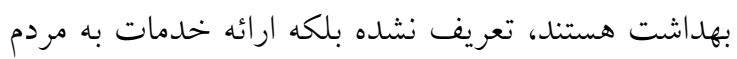

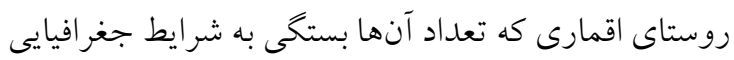
منطقهاى و جمعيتى دارد نيز از حوزه فعاليت اين بيام آوران بهان

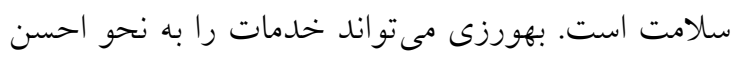
ارائه دهد كه از سطح سلامت اجتماعى بالايى برخوردار

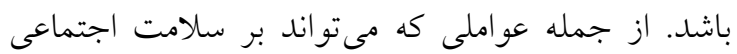

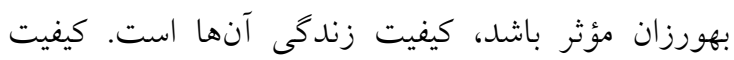

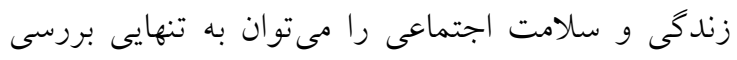

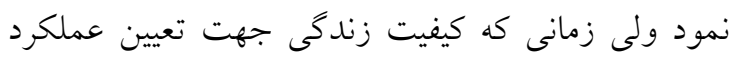
فيزيكى، روانى و اجتماعى بررسى شود اهميت بيشترى بيدا

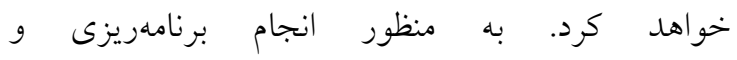

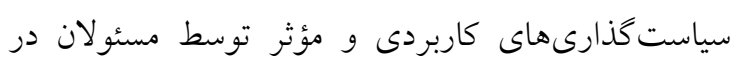

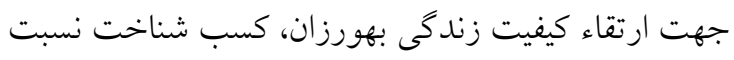
به سلامت اجتماعى و ابعاد آن و فوايد و عملكرد آن لازم و ضرورى به نظر مىرسد. بهورزان شاغل در خانههاى بهداشت شهرستانهاى قروه و دهگلان استان كردستان نيز از اين شرايط مستثنى نيستند. به خصوص اين ورهن كه استان

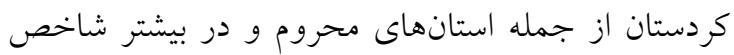
هاى اقتصادى، اجتماعى و فرهنگى گرفتار مانده و داراى وضعيت جغر افيايى نامناسب و روستاهاى صعب العبور مى باشد. بنابراين نيازهاى بهداشتى بهورزان بايد مورد توجه

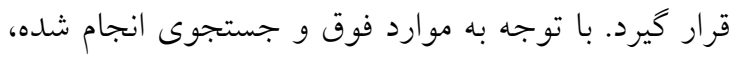

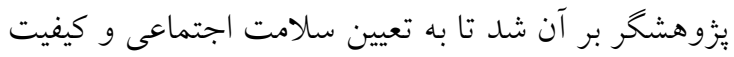

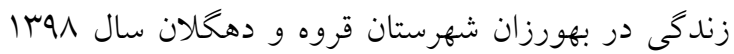
بيردازد. بر اساس بررسى هاى يُزوهشكر مطالعهاى با به اين

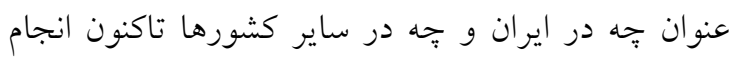


استفاده نموده و كزارش كردند كه آلفاى كرونباخ براى كل مقياس NA/ • و براى هر يك از خرده مقياس ها به به ترتيب

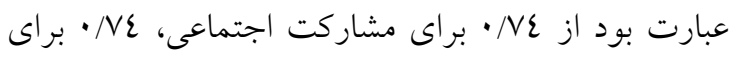

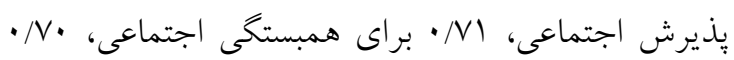

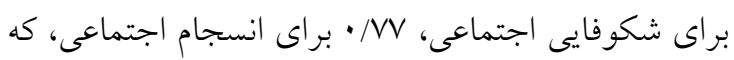

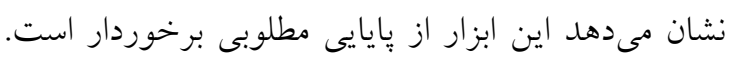

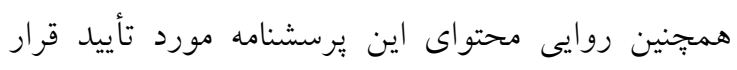
كر فته است (11)

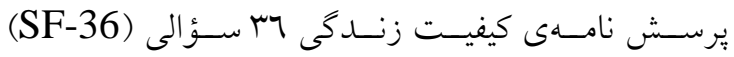

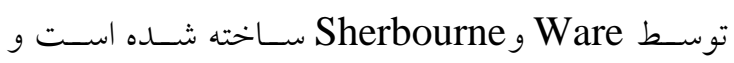

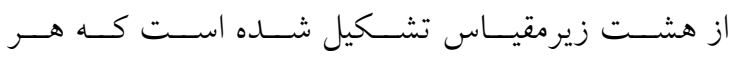
زيرمقيــاس متشــكل از ب تـــا · ا مــاده اســت. نمـــره

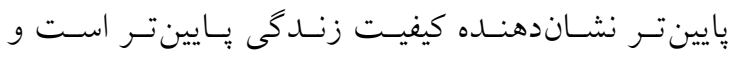
برعكس. زيرمقيـاسهـاى ايـن برسـش نامسه عبـارتانـــ

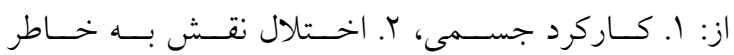
سـلامت جسـمىى، آ. اخــتلال نقـش بــه خـاطر سـلامت ع. هيجــانى. انرزى/خسـتـى 0. بهزيسـتى هيجــانى، 7.

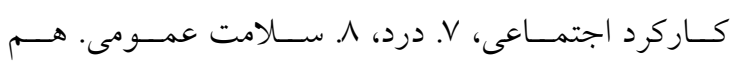
جنين از ادغـام زيرمقيـاسهــا دو زيرمقيـاس كلـى ديخــ به دست مى آيد كه عبارت اند از: زيرمقياس سلامت جسمى: جمع زيرمقياسهاى كاركرد جسمى، اختلال نقش به خاطر سلامت جسمى، درد و

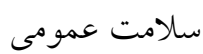

زيرمقياس سلامت روانى: جمع زيرمقياسهاى اختلال

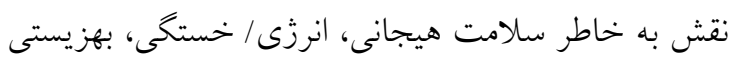
هيجانى و كاركرد اجتماعى. امتيازهاى هر مقياس از صفر تا صد متغير است كه صفر بدترين و صد بهترين وضعيت را در مقياس مورد نظر كزارش مى كند. براى كيفيت زندگى با ميانكين نظرى طيف برابر با •0 مىباشد. براى روايى و يايايى اين ابزار متظظرى و همكاران در سال ع^ґا در نسخه ايرانى تحليل آلفاى كرونباخ براى زيرمقياسهاى كاركرد جسمى •9/. ، اختلال نقش به خاطر سلامت جسمى 10/، اختلال نقش به خاطر سامت

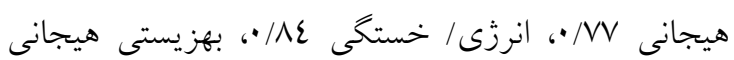

مخالفم (، مخالفم r، نظرى ندارم س، موافقم امتياز ع، وكاملاً موافقم 0 هستند. البته اين شيوه نمرهكذارى در مورد

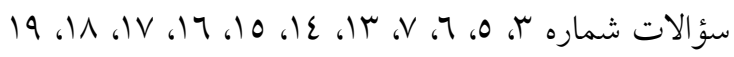

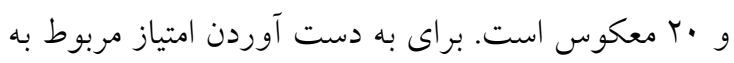
هر بعل، مجموع امتيازات سؤالات مربوط به آن بعل، با هم جمع مىشود و امتياز كلى از جمع امتيازات همه سؤالات حاصل مىشود. امتيازات بالاتر نشاندهنده سلامت اجتماعى بالاتر است. جّنان جّه نمره محاسبه شده بين r. تا حاع باشد، ميزان سلامت اجتماعى افراد در حد يايين و ضعيف بوده و بايد برنامهريزى اساسى براى آن انجام شود. جنان جّه نمره محاسبه شده بين عV-VV باشد سلامت اجتماعى در حد متوسط و رو به رشد و بايد تقويت شود.

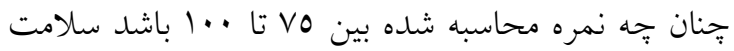
اجتماعى افراد در حد بالا و خوبى بوده و اين روند بايد تداوم يابد (9) ميانخين نظرى و تجربى طيف براى برسشنامه سلامت اجتماعى محاسبه شد. ميانخين نظرى طيف اين كونه محاسبه شده كه در مرحله اول تعداد گويههاى هر

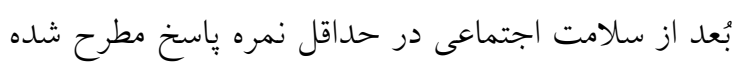
در طيف يعنى يك ضرب شده است. به عنوان مثال

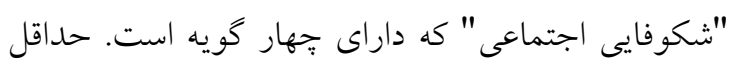
نمره طيف برابر با جهار مىشود. در مرحله دوم تعداد گويه هاى هر بُعد از سلامت اجتماعى در حداكثر نمره پِاسخ مطرح شده در طيف يعنى ينج ضرب مىشود. نمره اين

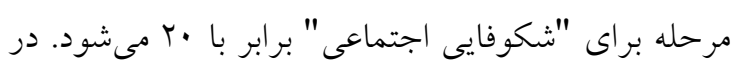

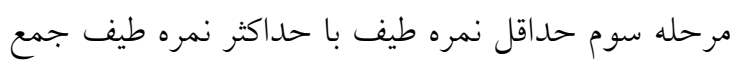
و تقسيم بر دو مىشود. در مثال شكوفايى اجتماعى جهار

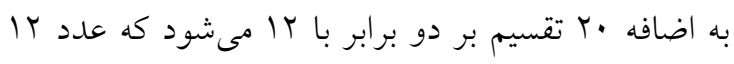
ميانخين نظرى طيف مىباشد. نحوه محاسبه ميانخين نظرى طيف براى ساير متغيرهاى سلامت اجتماعى نيز به همين شيوه محاسبه شده است. بايايى پرسشنامه سلامت اجتماعى در مطالعه هاشمى و همكاران، به صورت آلفاى كرونباخ عاملها بين عس/. تا

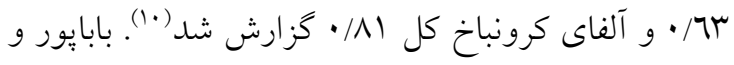
همكارانش براى بررسى بايايى اين ابزار از همسانى درونى ترنى 
شماره ( ) مشخصات جمعيت شناختى يا به عبارت ديخر

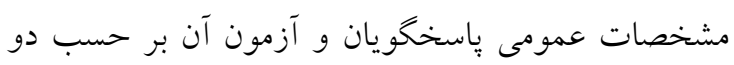
متغير سلامت اجتماعى و كيفيت زندكى ارائه شده است.

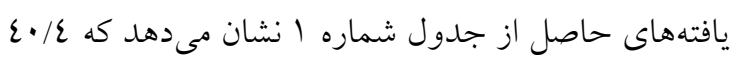

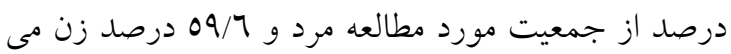

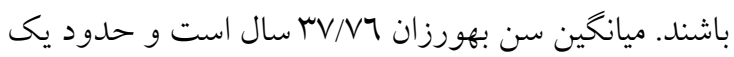

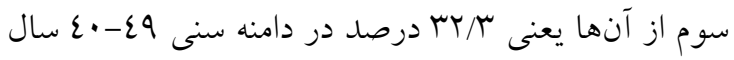

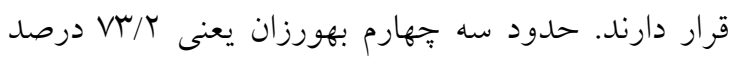

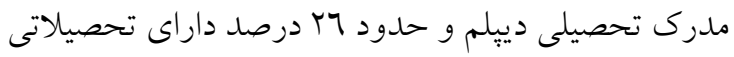
در سطح راهنمايى هستند. VN/T درصد از ياسخخويان

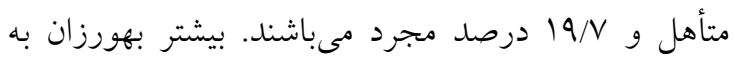
لحاظ وضعيت استخدامى داراى قرارداد رسمى هستند. جمعيت اين بهورزان بيش از VO درصد از كل جمعيت بهورزان را شامل مىشود. ميانخين سابقه شغلى بهورزان ع/V0

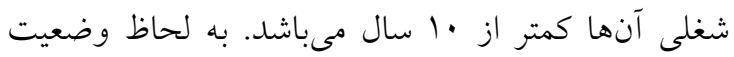

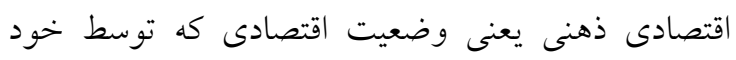
بهورزان مورد ارزيابى قرار كرفته است بايد كفت كه بيشتر

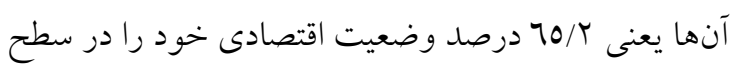

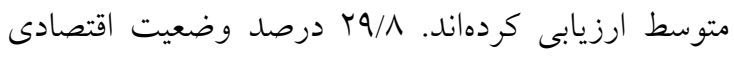

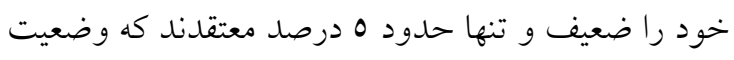
اقتصادى آنها خوب است. 79/V درصد داراى منزل

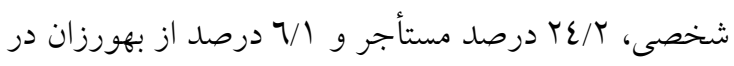
منازل دولتى ساكن هستند. به لحاظ وضعيت جسمانى نيز

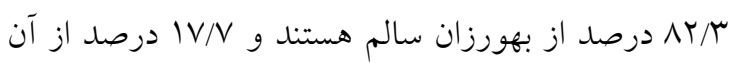
ها درگير بيمارى مى باشند.

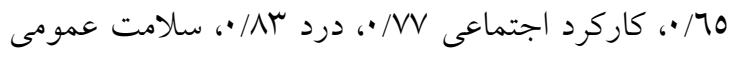

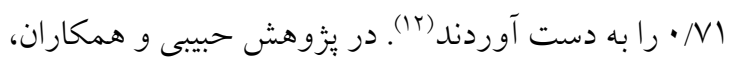

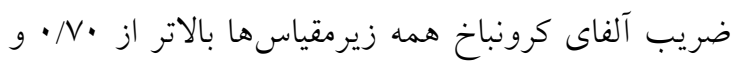

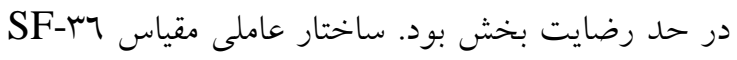

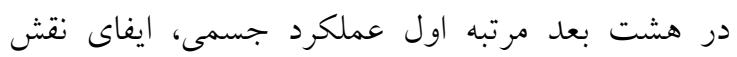

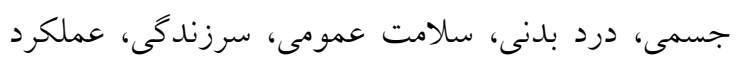
اجتماعى، ايفاى نقش هيجانى و سلامت روانى با استفاده

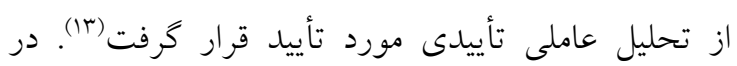

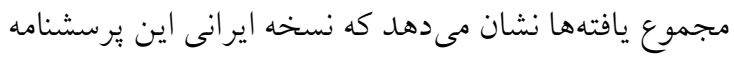

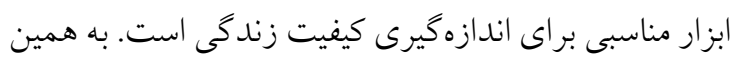
دليل بايايى و روايى در اين مطالعه انجام نشد. يُزوهشكر پِ از كسب اجازه از كميته اخلاق با كد IR.IUMS.FMD.REC 1398.378 دانشخاه و دريافت معرفى نامه از دانشخاه علوم يزشكى ايران

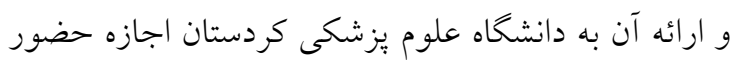

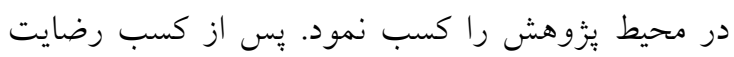

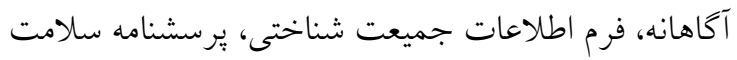

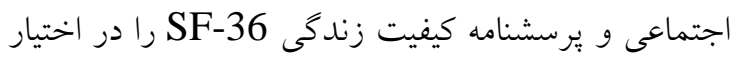

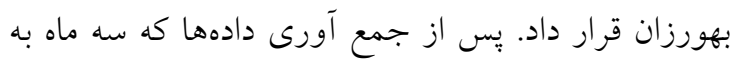

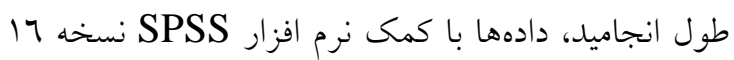

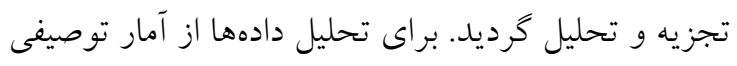

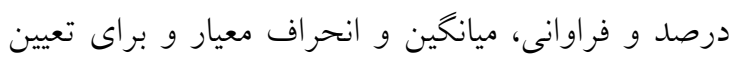

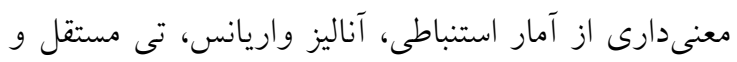
مقايسه دو به دوى توكى استفاده شد.

\section{يافتهها}

درصد يّاسخگويى صد در صد بود يعنى تمام بهورزان كه

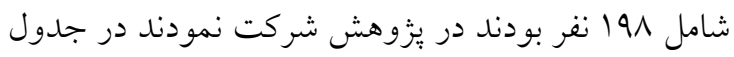


جدول شماره ا: مشخصات عمومى بهورزان و آزمون آن بر حسب سلامت اجتماعى وكيفيت زندكى

\begin{tabular}{|c|c|c|c|c|c|c|c|c|c|c|}
\hline \multicolumn{4}{|c|}{ كيفيت زندكى } & \multicolumn{3}{|c|}{ سلامت اجتماعى } & \multirow[b]{2}{*}{$\hat{\jmath}$} & \multirow[b]{2}{*}{$\frac{2}{\frac{2}{3}}$} & \multirow{2}{*}{\multicolumn{2}{|c|}{ متغير }} \\
\hline 3. & نتيجه آزمون & انحر اف & ميانحين & نتيجه آزمون & انحراف & ميانخين & & & & \\
\hline \multirow{2}{*}{$\begin{array}{l}3 \\
3 \\
3 \\
3\end{array}$} & \multirow{2}{*}{$\begin{array}{l}\mathrm{t}=\mathrm{r} / 02 \\
\mathrm{df}=197 \\
\mathrm{P}=. / \cdot 1\end{array}$} & $|\Lambda / \varepsilon|$ & TV/AY & \multirow{2}{*}{$\begin{array}{l}\mathrm{t}=1 / \Gamma \varepsilon \\
\mathrm{df}=197 \\
\mathrm{P}=\cdot / r \mathrm{r}\end{array}$} & $\mathrm{V} / 10$ & $v \cdot / l$ & $\varepsilon \cdot / \varepsilon$ & $\wedge \cdot$ & 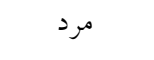 & \multirow[b]{2}{*}{ جنسيت } \\
\hline & & $r \mid / 9 r$ & $\tau \cdot / T \varepsilon$ & & $V / \varepsilon)$ & $T / N r$ & $09 / 7$ & 111 & زن & \\
\hline \multirow{4}{*}{ 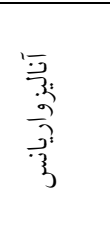 } & & $10 / 0 \mathrm{~V}$ & $V T / V r$ & \multirow{4}{*}{$\begin{array}{l}\mathrm{F}=r / r \varepsilon \\
\mathrm{P}=\cdot / \cdot v\end{array}$} & V/ro & $T V / V V$ & $r q / r$ & $0 \wedge$ & كمتر از •r & \multirow{4}{*}{ سن } \\
\hline & $F=r / 79$ & $1 \varepsilon / 99$ & $7 V / 10$ & & V/or & $7 / v q$ & $r \varepsilon / V$ & $\varepsilon 9$ & $r \cdot-r q$ & \\
\hline & $\mathrm{P}<\bullet / \cdot \cdot 1$ & $T r / \cdot r$ & $0 . / V Y$ & & V/ro & $V I / T O$ & $r T / r$ & $7 \varepsilon$ & $\varepsilon \cdot-\varepsilon q$ & \\
\hline & & IV/qr & $O V / T V$ & & $\Lambda / \varepsilon V$ & $T / \mathrm{VV}$ & $1 \pi / 7$ & TV & •0 و بالاتر & \\
\hline \multirow{2}{*}{$\begin{array}{l}3 \\
3 \\
3 \\
3\end{array}$} & $t=r / 09$ & $r \cdot / R \varepsilon$ & $O \varepsilon / T T$ & \multirow{2}{*}{$\begin{aligned} \mathrm{t}= & =1 / \cdot r \mathrm{df} \\
& =19 \varepsilon \\
\mathrm{P} & =\cdot / r 1\end{aligned}$} & $N / 1 Y$ & $v \cdot / 10$ & ro/A & 01 & راهنمايى & \multirow{2}{*}{ تحصيلى } \\
\hline & $\begin{array}{c}d f=19 \varepsilon \\
P<\cdot / \cdot \cdot 1\end{array}$ & $r \cdot / r q$ & $77 / 17$ & & $V / \varepsilon r$ & $71 / 19$ & $V \mu / r$ & $1 \varepsilon 0$ & دييلم & \\
\hline \multirow{2}{*}{$\begin{array}{l}3 \\
3 \\
3 \\
3\end{array}$} & $t=\varepsilon / \cdot \wedge$ & $10 / 71$ & $V Y / V T$ & \multirow{2}{*}{$\begin{aligned} \mathrm{t} & =1 \mathrm{df} \\
& =19 \mathrm{r} \\
\mathrm{P} & =\cdot / \mathrm{r}\end{aligned}$} & N/Or & $v \cdot / T_{0}$ & $19 / V$ & rq & مجرد & \multirow{2}{*}{ تأهل } \\
\hline & $\begin{array}{l}\mathrm{df}=19 \mathrm{r} \\
\mathrm{P}<\cdot / \cdot \cdot 1\end{array}$ & $r \cdot / v q$ & $71 / \varepsilon r$ & & $V / \varepsilon \varepsilon$ & $7 / / 9 \Lambda$ & $V \Lambda / r$ & 100 & متأهل & \\
\hline \multirow{3}{*}{$\begin{array}{l}\frac{9}{3} \\
\frac{3}{3} \\
\frac{3}{3} \\
3\end{array}$} & $F=1 / 01$ & $10 / N Y$ & $\mathrm{VV} / \mathrm{AV}$ & \multirow{3}{*}{$\begin{array}{l}\mathrm{F}=\cdot / \cdot r \\
\mathrm{P}=\cdot / 9 \mathrm{~V}\end{array}$} & V/ru & $79 / 10$ & $19 / 4$ & $\mu_{\Lambda}$ & شركتى & \multirow{3}{*}{ وضعيت } \\
\hline & $\mathrm{P}<\cdot / \cdot \cdot 1$ & $|r / T|$ & $V V / 09$ & & $V / 0 \varepsilon$ & $79 / 11$ & $0 / 7$ & 11 & بيمانى & \\
\hline & & $r \cdot / \mu \Lambda$ & ON/Or & & $V / V I$ & $79 / Y \Lambda$ & Vo/r & $1 \varepsilon 9$ & رسمى & \\
\hline \multirow{3}{*}{ 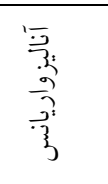 } & $F=\varepsilon / \wedge \mid$ & $10 / 47$ & $V \varepsilon / \mu\urcorner$ & \multirow{3}{*}{$\begin{array}{l}\mathrm{F}=\backslash / \widetilde{V} \\
\mathrm{P}=\cdot / r\urcorner\end{array}$} & $7 / 97$ & $71 / 49$ & $\varepsilon 1 / \varepsilon$ & NT & كمتر از • & \multirow{3}{*}{ سابقه } \\
\hline & & $M / Y$ & $T / \wedge r$ & & $1 / 90$ & $v \cdot / 7 r$ & $17 / V$ & r & $1 \cdot-19$ & \\
\hline & & $19 / 20$ & 0.111 & & $V / 7$ & $79 / V \pi$ & $19 / \mathrm{V}$ & $\wedge r$ & • r به بالا & \\
\hline \multirow{3}{*}{ 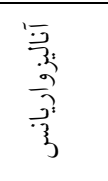 } & $F=r / r V$ & & & \multirow{3}{*}{$\begin{array}{l}\mathrm{F}=r / \cdot 1 \\
\mathrm{P}=\cdot / \cdot \bullet\end{array}$} & $O / V I$ & $7 \varepsilon / 7$ & $0 / 1$ & 1. & خوب & \multirow{3}{*}{ وضعيت } \\
\hline & $P=\cdot / \cdot \varepsilon$ & $1 \Lambda / V V$ & $70 / \mathrm{AV}$ & & $V / r q$ & $V \cdot / \cdot 0$ & $70 / r$ & $1 Y 9$ & متوسط & \\
\hline & & $r \varepsilon / 7$ & $O V / O V$ & & N/YO & $T / \varepsilon$ & $r q / 1$ & 09 & ضعيف & \\
\hline \multirow{3}{*}{ 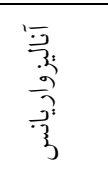 } & $F=\varepsilon / \wedge 0$ & $19 / 09$ & $70 / 199$ & \multirow{3}{*}{$\begin{array}{l}\mathrm{F}=0 / 0 r \\
\mathrm{P}=/ . .0\end{array}$} & $V / 71$ & $v \cdot / r y$ & $79 / V$ & IrN & شخصى & \multirow{3}{*}{ وضعيت } \\
\hline & $P=\cdot / \cdot \cdot q$ & $r r / 9 \Lambda$ & $00 / 00$ & & $V / \cdot 9$ & $T T / Y Y$ & $r \varepsilon / T$ & $\varepsilon \wedge$ & اجارهاى & \\
\hline & & Ir/Ar & $V \cdot / T_{0}$ & & $T / 7 r$ & $79 / \cdot 1$ & $7 / 1$ & Ir & دولتى & \\
\hline \multirow{2}{*}{$\begin{array}{l}3 \\
3 \\
3 \\
3\end{array}$} & $t=0 / 17$ & $r \cdot / 9 T$ & $\varepsilon V / V\urcorner$ & $\mathrm{t}=1 / 20 \mathrm{df}$ & $0 / 7$ & $7 V / 7$ & $I V / V$ & ro & دارد & وضعيت \\
\hline & $\begin{array}{l}\mathrm{df}=197 \\
\mathrm{P}<\cdot / . .1\end{array}$ & $19 / 40$ & $77 / 7 \varepsilon$ & $\begin{array}{c}=197 \\
P=\cdot / 10\end{array}$ & V/ar & $79 / 70$ & $\Lambda T / r$ & $17 \pi$ & 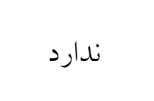 & بيمارى \\
\hline
\end{tabular}

طيف است. نمره ميانخين بذيرش اجتماعى بهورزان اندكى هايينتر از ميانخين نظرى طيف است. در ميان ابعاد مختلف سلامت اجتماعى بيشترين اختلاف نمره متغيرها با ميانخين نظرى به ترتيب مربوط به متغيرهاى انسجام اجتماعى، مشاركت اجتماعى و شكوفايى اجتماعى است. در ارتباط با كيفيت زندگى بهورزان نيز نمره ميانخين اين متغير بالاتر
شاخصهاى عددى سلامت اجتماعى و كيفيت زندگى و ابعاد آن در جدول شماره r نشان داده شده است. نتايج حاصل از جدول شماره r نشان مىدهد كه سلامت اجتماعى بهورزان بالاتر از ميانخين نظرى اين متغير مى باشد. در ميان ابعاد سلامت اجتماعى تمامى ابعاد به استثناى "يذيرش اجتماعى" ميانخين آنها بالاتر از ميانخين نظرى 
و سلامت عمومى) و سلامت روانى بهورزان (شامل اختلال

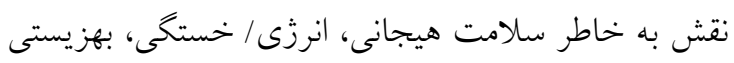
هيجانى و كاركرد اجتماعى) است.
از ميانخين نظرى مىباشد. كيفيت زندگى بهورزان مانند

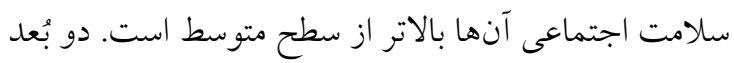
اصلى كيفيت زندگى سلامت جسمى بهورزان (شامل ابعاد باد كاركرد جسمى، اختلال نقش به خاطر سلامت جسمى، درد

جدول شماره r: شاخصهاى عددى سلامت اجتماعى و كيفيت زندَّى و ابعاد آنها در بهورزان مورد يزوهش

\begin{tabular}{|c|c|c|c|c|}
\hline انحراف معيار & ميانگين تجربى طيف & ميانگين نظرى طيف & متغير و ابعاد آن & \\
\hline$V / 7$ & $79 / \Upsilon 1$ & 7. & سلامت اجتماعى & \\
\hline$T / \tau \varepsilon$ & $1 \varepsilon / v$. & ir & شكوفايى اجتماعى & \\
\hline$T / N V$ & $9 / 20$ & 9 & همبستى اجتماعى & سلامت اجتماعى \\
\hline$r / \cdot r$ & $I T / T V$ & 9 & انسجام اجتماعى & و ابعاد آن \\
\hline$r / r$. & $1 \varepsilon / \wedge \varepsilon$ & 10 & لِذيرش اجتماعى & \\
\hline$r / \Lambda$ & $1 N / \cdot 1$ & 10 & مشاركت اجتماعى & \\
\hline$r \cdot / \mathrm{AV}$ & $7 \pi / \mu$ & 0. & كيفيت زندكى & \\
\hline$r \varepsilon / 01$ & $7 \Gamma / 10$ & 0. & سلامت جسمى & \\
\hline$r 1 / r q$ & $T / / N O$ & 0. & سلامت روانى & \\
\hline$r q / v \varepsilon$ & $v \pi / r o$ & 0. & كاركرد جسمى & \\
\hline$r_{\Lambda / 91}$ & $71 / T V$ & 0. & اختلال نقش به خاطر سلامت جسمى & كيفيت زندگى و \\
\hline$\varepsilon r / 00$ & $0 N / Y T$ & 0. & اختلال نقش به خاطر سلامت هيجانى & ابعاد آن \\
\hline rI/OV & $T r / M T$ & 0. & انرزى/خستخى & \\
\hline $19 / \wedge \varepsilon$ & $70 / \mathrm{NT}$ & 0. & بهزيستى هيجانى & \\
\hline$r r / T V$ & $T \xi / \Lambda$ & 0. & كاركرد اجتماعى & \\
\hline$r V / 0 \varepsilon$ & $7 r / 9 V$ & 0. & درد & \\
\hline rI/VE & OV/AT & 0. & سلامت عمومى & \\
\hline
\end{tabular}

ميانخين نظرى طيف= ميانه ابزار

كيفيت زندكى بهورزان بر حسب همه متغيرهاى جمعيت

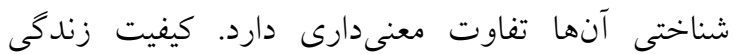
بهورزان بر حسب جنسيت تفاوت معنىدارى دارد. نتايج

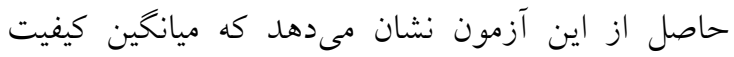
زندكى مردان به صورت معنى دارى بيشتر از ميانخين كيفيت

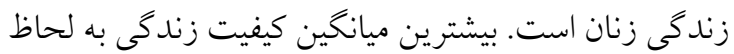

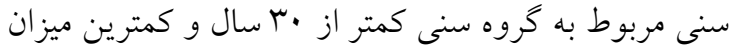
اين متغير نيز براى كروه سنى •ع تا وهع سال با ميانخين 0./V مىباشد. به لحاظ وضعيت تحصيلى نيز كيفيت

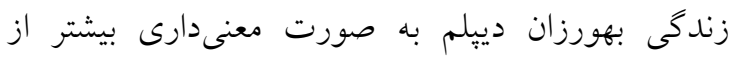
ميانخين كيفيت زندگى بهورزان داراى تحصيلات راهنمايى
بر اساس يافتهاى حاصل از جدول شماره ا، جنس، سن، وضعيت تحصيلى، وضعيت تأهل، وضعيت شغلى، سابقه شغلى و وضعيت بيمارى با سلامت اجتماعى بهورزان ارتباط معنىدارى ندارد. وضعيت اقتصادى بهورزان و وضعيت مسكن آنها با سلامت اجتماعى ارتباط معنىدارى دارند (P</0). Pيشترين ميانخين سلامت اجتماعى به ترتيب مربوط به بهورزانى است كه وضعيت اقتصادى خود را متوسط، ضعيف و خوب ارزيابى كردهاند. ميانخين سلامت اجتماعى بهورزانى كه داراى منزل مسكونى شخصى هستند بيشتر از خروههاى ديخر است. 
حد متوسط بود(ع) و در يزوهش زكى و خشوعى نيز

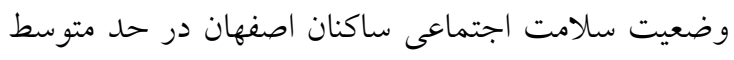

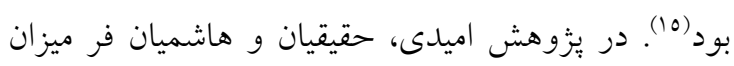

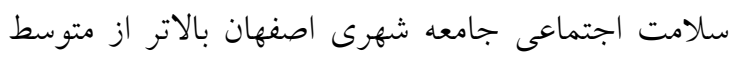

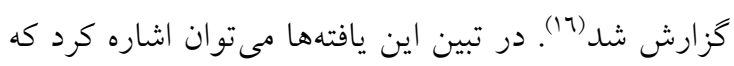

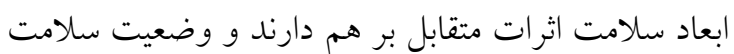

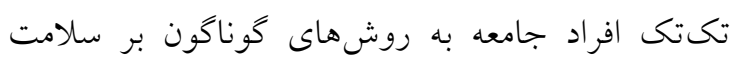

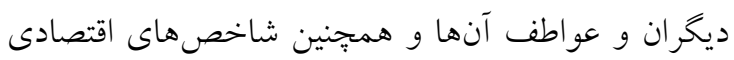
و اجتماعى جامعه اثر مى گذارد؛ به عنوان مثال بعد اجتماعى لهى سلامت اثرات بيشخيرانه بر روى دو بعد جسمى و روانى

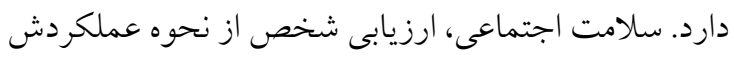

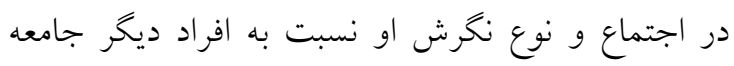

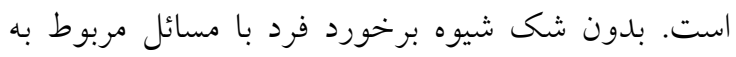

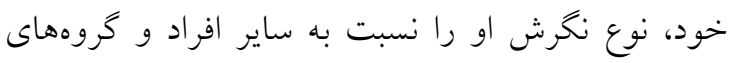

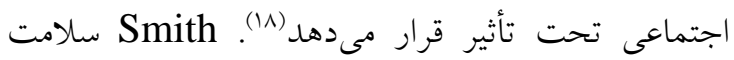
اجتماعى را "ارزيابى رفتارهاى معنى دار مثبت و منفى فرد

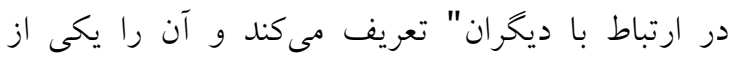

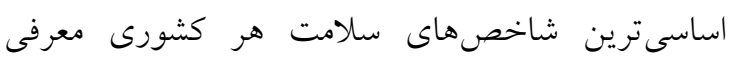

مى كند كه به كارا بودن فرد در جامعه منجر مى گرددد (19).

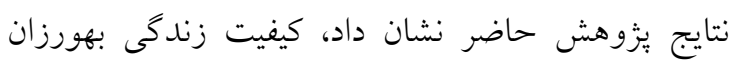
مانند سلامت اجتماعى آنها بالاتر از سطح متوسط است.

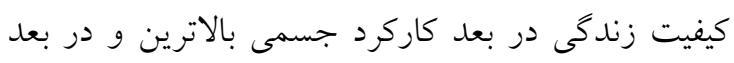

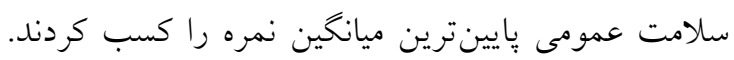

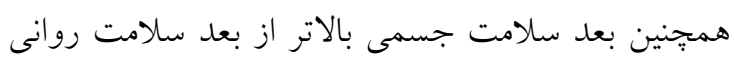

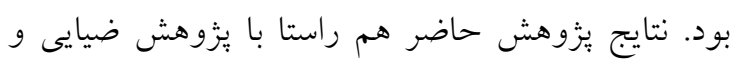

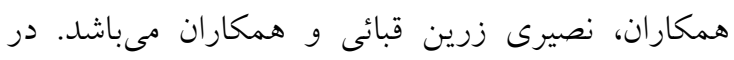

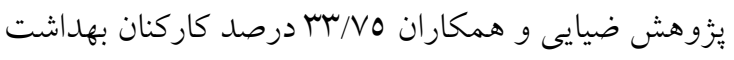

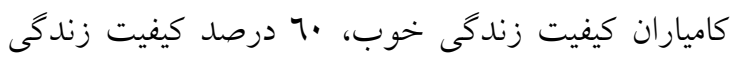

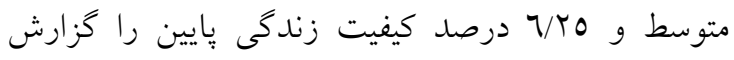

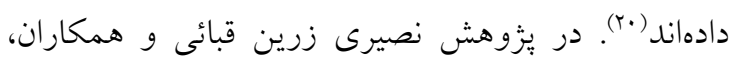

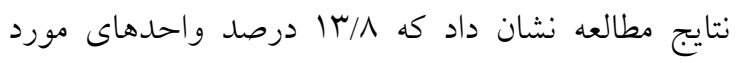

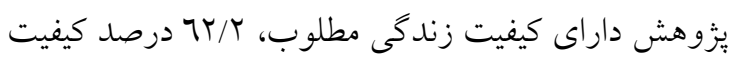
زندكى متوسط و ع ب درصد داراى كيفيت زندكى دارئ زياين

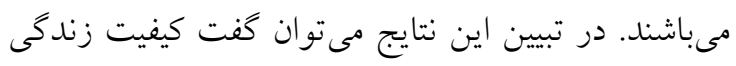

است. كيفيت زندكى بهورزان مجرد به صورت معنى دارى

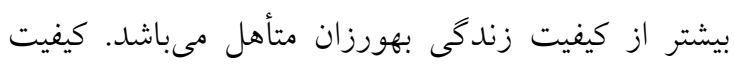

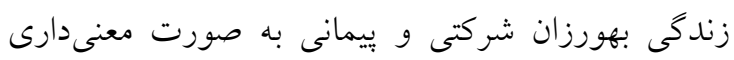

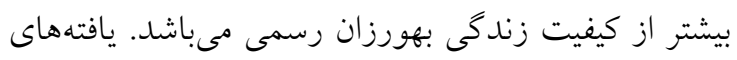

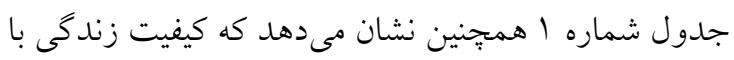

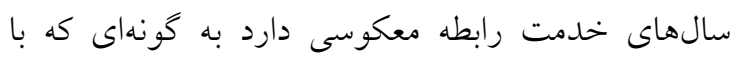
افزايش سابقه شغلى در كروههاى طبقه بندى شده كيفيت

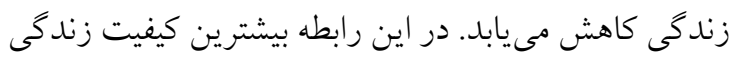

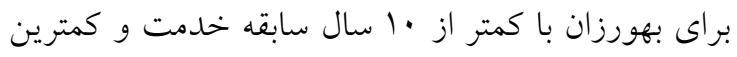

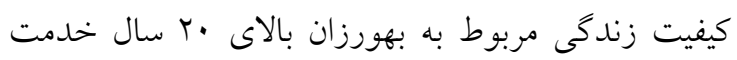

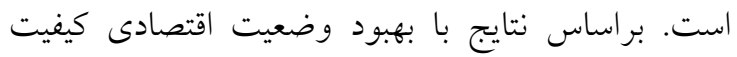

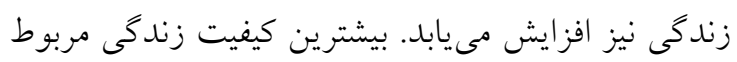

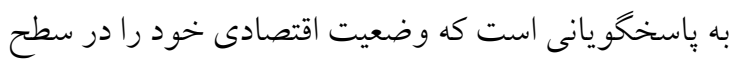

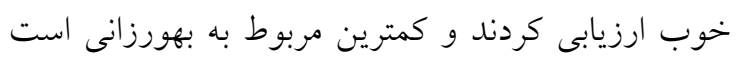
كه وضعيت اقتصادى خود را ضعيف مىدانند. كيفيت

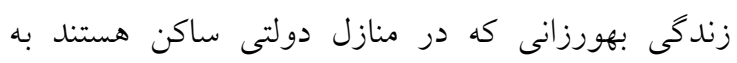

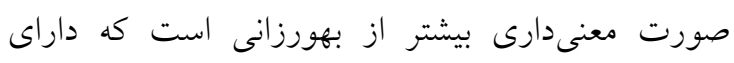
ملكيت منزل مسكونى يا مستأجر هستند. بر اساس يافته

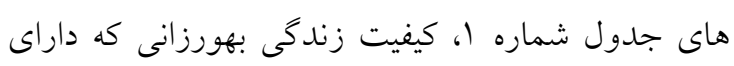

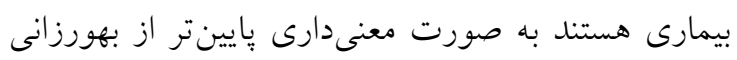
است كه فاقد هر گونه بيمارى مىباشند.

\section{بحث و نتيجه تيرى}

نتايج يزوهش حاضر نشان داد سلامت اجتماعى بهورئران بالاتر ازسطح متوسط مىباشد. و بالاترين و وِايينترين

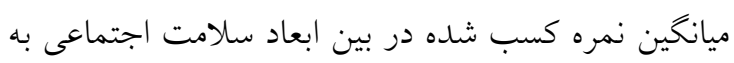

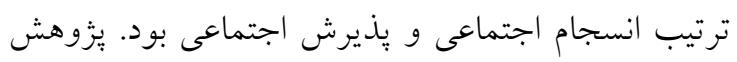

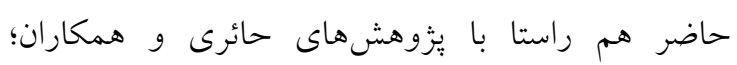

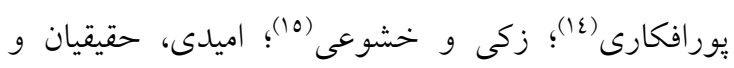
هاشميان فر(17) مى باشد. در يُزوهش حائرى و همكاران

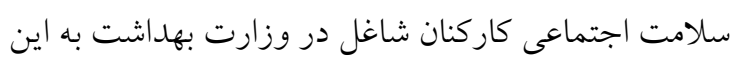
صورت بود كه 01/V درصد سلامت اجتماعى متوسط و IV/A

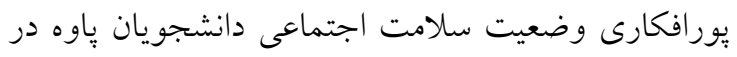


سطح سلامت اجتماعى نيز افزايش مىيابد. با توجه به اين

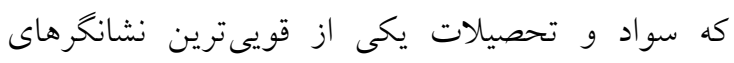

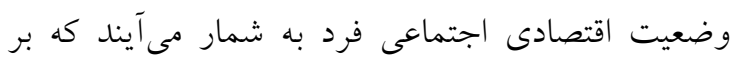

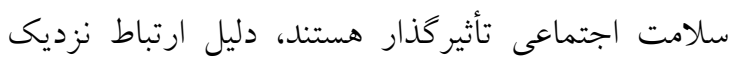
تحصيلات با سلامت اجتماعى از سه مقوله شرايط اقتصادى ليرى

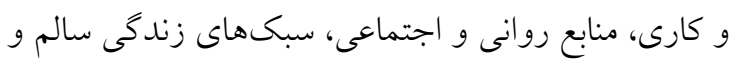
بهداشتى قابل بررسى است (rع).

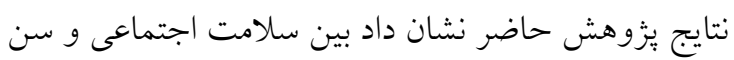
رابطه معنى دارى وجود ندارد. در تبين اين يافته مىتوان

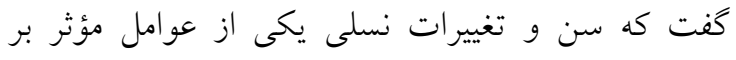

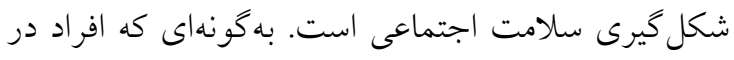

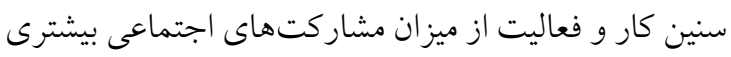
برخوردار هستند و اتفاقاتى كه براى يك نسل اتفاق افتاده

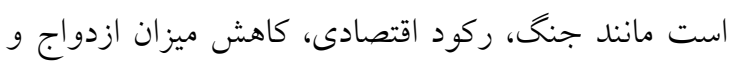
افزايش نرخ طلاق، كاهش تعداد فرزندان بر سلامت

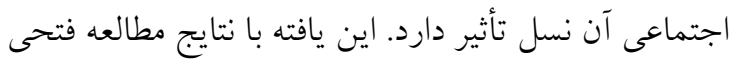

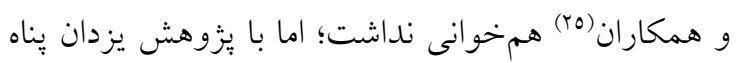

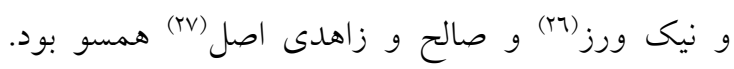

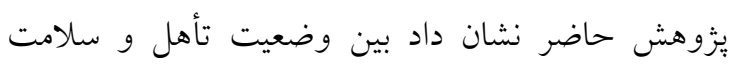

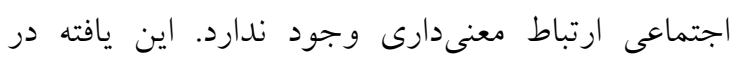

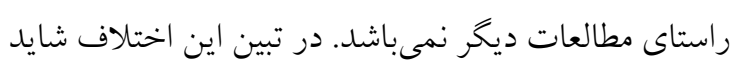

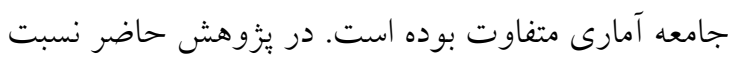
زن به مرد بيشتر مىباشد، همجنين مقطعى بودن و خود

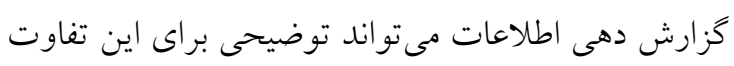

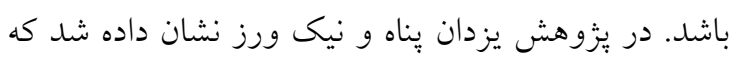

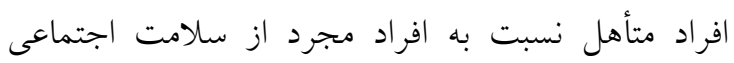

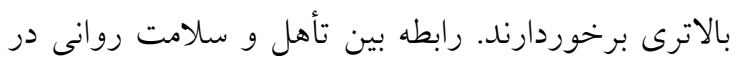

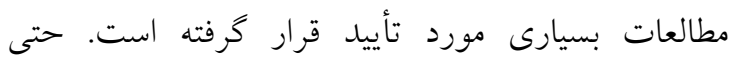
نظريهيردازان سلامت اجتماعى نيز بر اين رابطه تأكيد

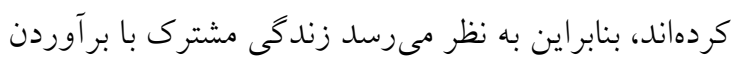

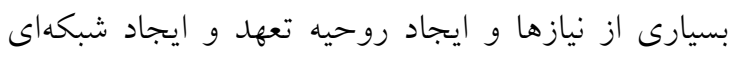
پايدار از روابط، موجب نخرش مثبت فرد نسبت به امور اجتماعى و در نتيجه بالا رفتن ميزان سلامت اجتماعى مى بـ
يكى مفهوم : جندبعدى است و بهعنوان احساس نشاط و

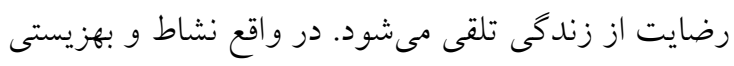
نوعى ارزشيابى ذهنى از تجارب فردى در حيطههاى

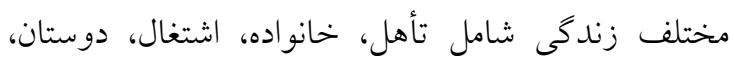

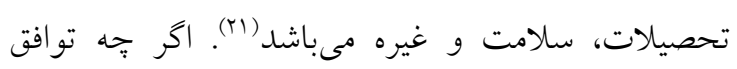

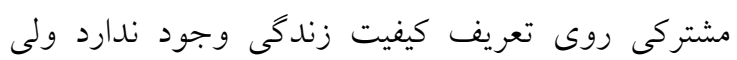
اغلب تعاريف در حول و حوش رضايت از زندكى متمركز

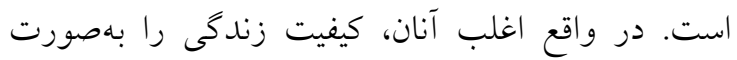

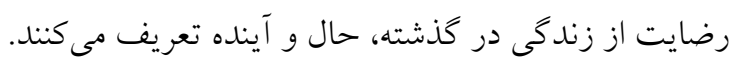
Frish

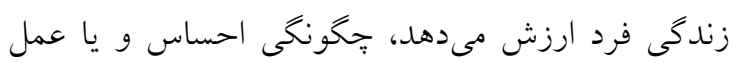

$$
\text { فرد در زندگى روزانه مى داند (Yr). }
$$

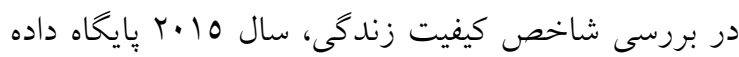

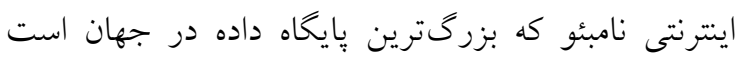

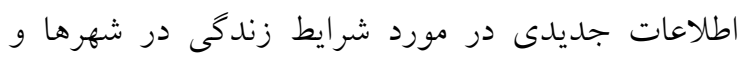
كشورهاى جهان ازجمله هزينههاى زندگى، شاخص

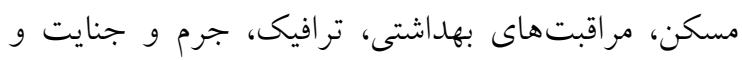

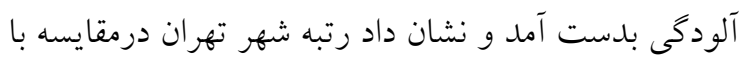

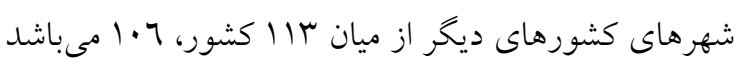
كه اين عدد وضعيت نامناسب كشور ايران را نشان مىدهد. اكر جهه نمى توان جمعيت افراد ساكن در تهران را به به كل

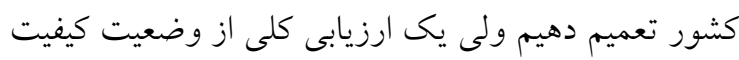

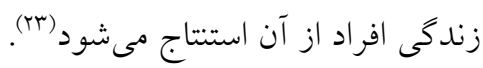

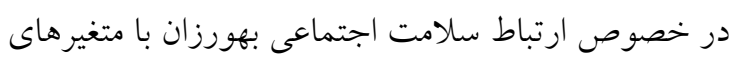

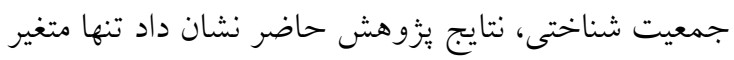

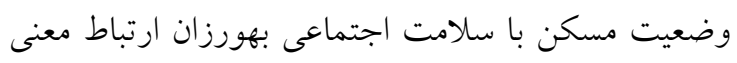

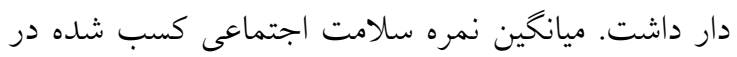
بهورزان با منزل شخصى به طور معنى دارى بالاتر از اجاره

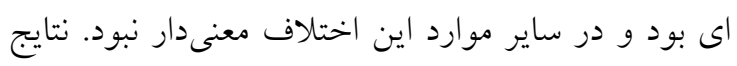
يزوهش حاضر هم راستاى يزوهش حائرى و همكاران و

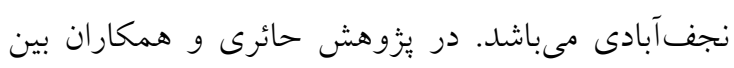

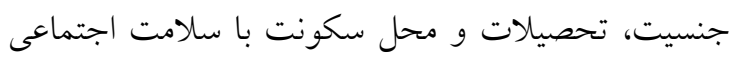

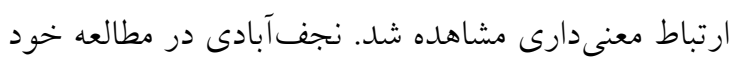

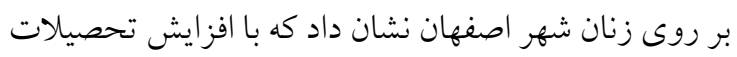


نحوى كه در خصوص متغير جنس سطح كيفيت زندكى در مردان بيشتر از زنان بود.

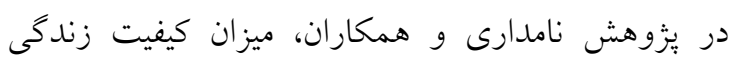

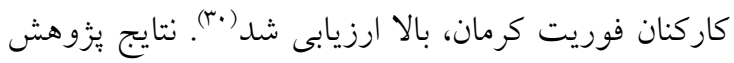

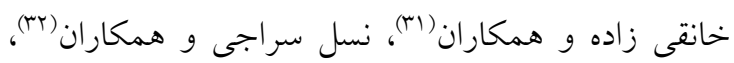

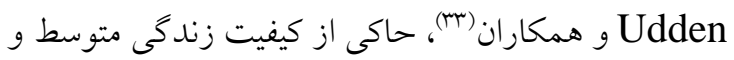

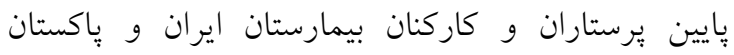
مىباشد. در اين يزوهش ها بين وضعيت اقتصادى، سابقهاى

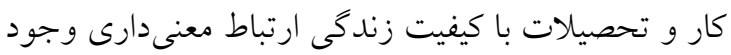

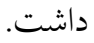

در يزوهش حاضر وضعيت اقتصادى با كيفيت زندكى از

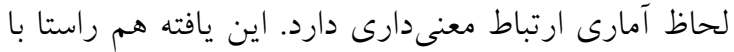
يزوهش نامدارى و همكاران، نسل سراجى و همكاران و خانقى زاده و همكاران مىباشد. بر اساس تئورى بايخاه اجتماعى، وضعيت اجتماعى و اقتصادى بر سلامت انسان

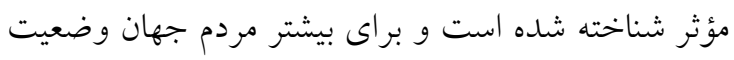

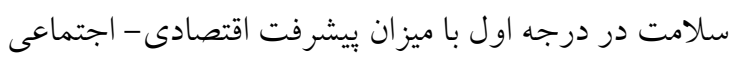
يعنى درآمد سرانه، سطح آموزش، تغذيه، و اشتغال تعيين

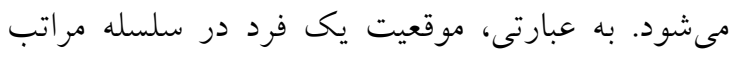
اجتماعى براى وى شر ايط و ويزّى هايى را فراهم مى كند بند

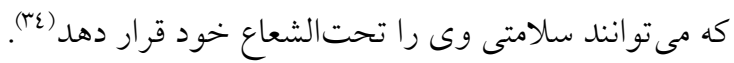

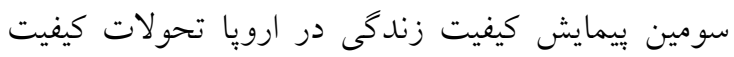
زندگى را در آن منطقه مورد بررسى قرار داده است. در اين زين

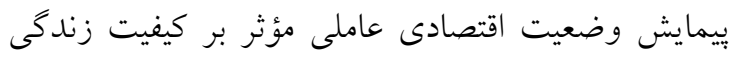

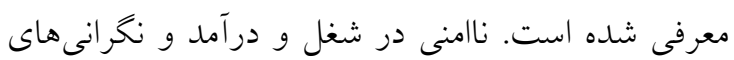

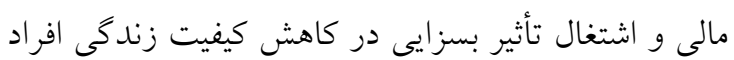

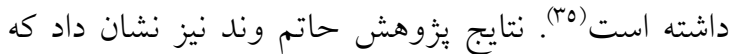
بين اشتغال، درآمد و كيفيت زندكى رابطه معنى دارى وجود دارد (ro)

يافتهها نشان داد سلامت اجتماعى و كيفيت زندكى بهورزان بالاتر از حد متوسط بود. هر اندازه كيفيت زندگى به طور مستمر ارتقاء يابد به همان ميزان از آسيبها و اختلالات روانشناختى و نارضايتى از زندكى كاسته مى هود. سلامت

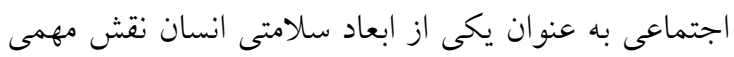

نتايج يزوهش حاضر نشان داد همه متغيرهاى جمعيت شناختى بهورزان با كيفيت زندكى ارتباط معنى دارى دارند.

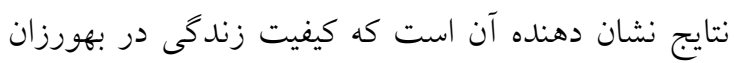

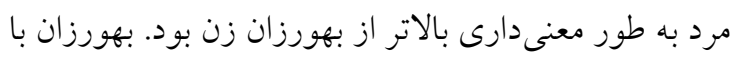

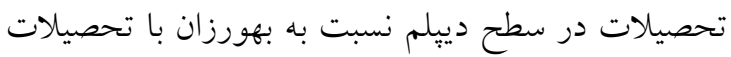

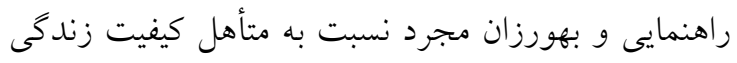

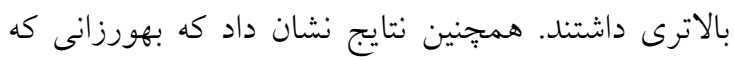
سابقه بيمارى نداشتند كيفيت زندكى بالاترى نسبت به به به

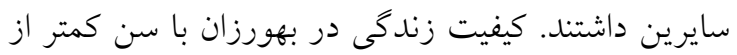
•r سال به طور معنى دارى بالاتر از بهورزان •ع تا وحع سال

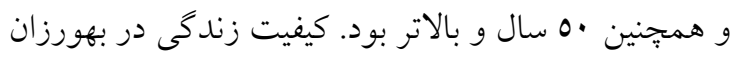

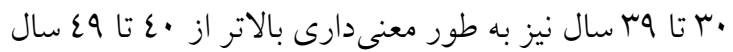

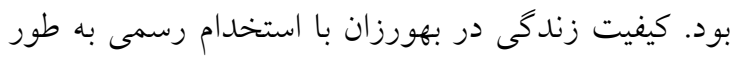

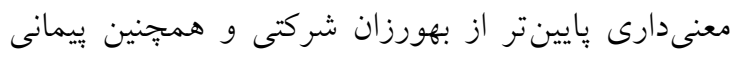

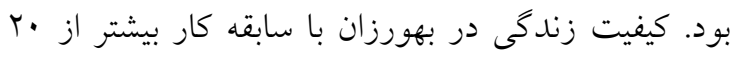

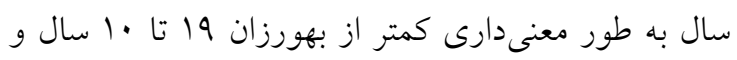

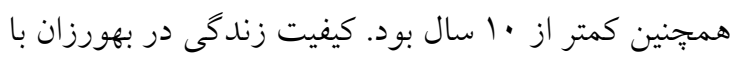
وضعيت اقتصادى ضعيف به طور معنىدارى يايين تر از متوسط بود و در ساير سطوح اين اختلاف معنىدار نبود.

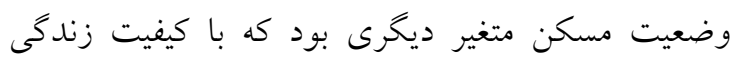

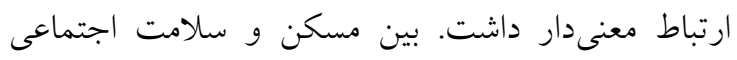

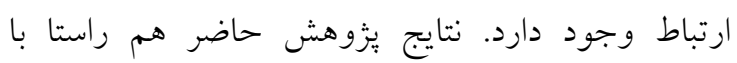

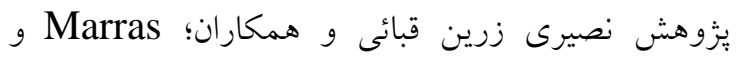

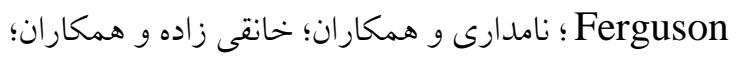
نسل سراجى و همكاران و Udden و همكاران مىباشد. در يزوهش نصيرى زرين قبائى و همكاران، نتايج مطالعه

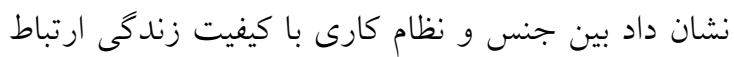

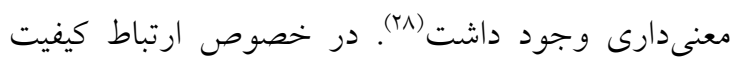

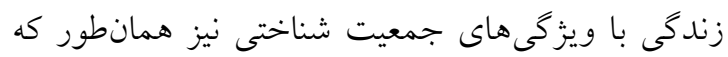
Marras آسيبهاى حاصله بر شرايط و كيفيت زندگى مؤثر دانسته

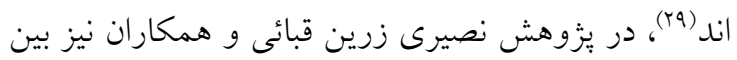

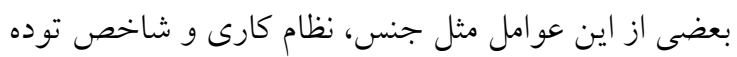

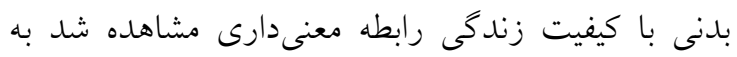




$$
\begin{aligned}
& \text { تقدير و تشكر } \\
& \text { اين مقاله بر گرفته از بايان نامه كارشناسى ارشد يِرستارى }
\end{aligned}
$$

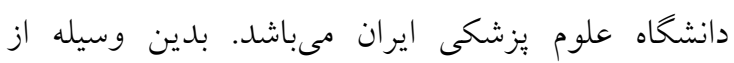

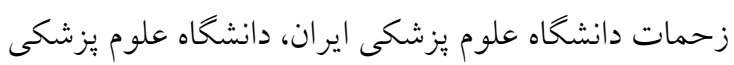

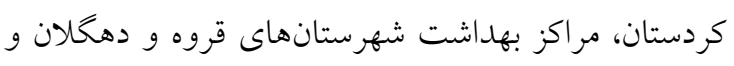

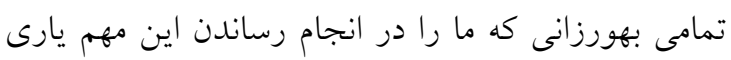

$$
\begin{aligned}
& \text { نمودهاند نهايت تشكر و قدردانى را داريم. }
\end{aligned}
$$

\section{References}

1. Naseem K. Job stress, happiness and life satisfaction: The moderating role of emotional intelligence empirical study in telecommunication sector Pakistan. J Social Sci Human Stud. 2018;4(1):7-14.

2. Van Ommeren M, Saxena S, Saraceno B. Mental and social health during and after acute emergencies: emerging consensus?. Bulletin of the World Health Organization. 2005;83:71-5

3. Keyes CL. Subjective well-being in mental health and human development research worldwide: An introduction. Soc Indicat Res. 2006;77(1):1-10.

4. Samiee M, Rafiee H, Amini RM, Akbarian M. Social health of Iran: from a consensus-based definition to an evidence-based index.. Social Problems of Iran (Journal Of Kharazmi University) 2011;1(2):31-51. [Persian]

5. Zamankhani F, Abachizadeh K, Omidnia S, Abadi A, Hiedarnia MA. Social health situation analysis of all provinces of Islamic republic of Iran. Commonity Health. 2016;3(3):181-9. [Persian]

6. World Health Organization. Global technical strategy for malaria 2016-2030. World Health Organization; 2015 Nov 4.

7. Keyes CL, Shapiro AD. Chapter Twelve. Social Well-Being in the United States: A Descriptive Epidemiology. University of Chicago Press; 2019 Jun 25.

8. Hajlo N. The relationship of staffs' job stress, burnout, and life quality to organizational climate satisfaction at Mohaghegh Ardabili University. Journal of New Approaches in Educational Administration. 2012;3(11):169-84. [Persian]

9. Keyes CLM, Shapiro AD. Social Well-Being in the United States: A Descriptive Epidemiology. How healthy are we?: A national study of well-being at midlife. The John D. and Catherine T. MacArthur foundation series on mental health and development. Studies on successful midlife development. Chicago, IL, US: University of Chicago Press; 2004: 350-72.

10. Hashemi T, Hekmati I, Vahedi SH. Psychometric properties of short-form social well-being questionnaire. Journal of Behavioral Sciences. 2014;8(1):11-9. [Persian]

11. Babapour Kheiroddin J, Toosi F, Hekmati I. Study of determinant factors role of students' social well-being. Journal of Modern Psychological Researches. 2010;4(16):1-9. [Persian]

12. Montazei A, Goshtasbi A, VahdaniNia M. Translation, determination of the reliability and validity of Persian species of Standard tools SF-36. Quarterly monitoring. 2005;5(1):49-56. [Persian]

13. Habibi M, Pooravari M, Salehi S, Ghamkhar Fard Z, Pooravari M. Validity and reliability of the multidimensional student's life satisfaction scale among Iranian girl students. Journal of Research and Health. 2015;5(1):65-73. [Persian]

14. Pourafkari N. The examination of factor affecting on social health' students in Paveh city. Quarterly Professional Journal of Social Sciences. 2011;6(18):41-60. [Persian]

15. Zaki MA, Khoshouei MS. Factors affecting social well-being of the residents of the city of Isfahan. Urban Studies. 2013;3(8):79-108. [Persian]

16. Omidi M, Haghighatian M, Hashemianfar SA. Social Well-Being and its Functions in Urban Areas (Case of Study: Metropolis of Esfahan). Urban Sociological Studies. 2017;7(24):157-88. [Persian] 
17. Haery M, Tehrani H, Olyaeimanesh AR, Nedjat S. Factors influencing the social health of employees of the ministry of health and medical education in Iran. Iran J Health Educ Health Promot. 2016;3(4):311-18. [Persian]

18. Van Ommeren M, Wessells M. Inter-agency agreement on mental health and psychosocial support in emergency settings. Bulletin of the World Health Organization. 2007;85(11):822-3.

19. Smith KP, Christakis NA. Social networks and health. Annu. Rev. Sociol. 2008;34:405-29.

20. Ziaei M, Hosseini SY, Shariati H, Khoshboo E. Association between occupational burnout and quality of life among healthcare workers. Journal of Safety Promotion and Injury Prevention. 2015;3(3):185-90. [Persian]

21. Mukhopadhyay M. Quality management in higher education: SAGE Publications India; 2016.

22. Liu L. Quality of life as a social representation in China: A qualitative study. Soc Indic Res. 2006;75(2):217-40.

23. NUMBEO. Quality of Life Index Rate 2015 [cited 20185 Jul]. Available from: https://www.numbeo.com/quality-of-life/rankings.jsp?title=2015.

24. Braveman P, Egerter S, Williams DR. The social determinants of health: coming of age. Ann Rev Public Health. 2011;32:98.

25. Fathi M, Ajamnejad R, Khakrangin M. Factors contributing to social health among teachers of Maraghe city. Social Welfare Quarterly. 2013;12(47):225-43. [Persian]

26. Nikvarz T, Yazdanpanah L. Relationship between Social Factors and Social Health among Students of Shahid Bahonar University of Kerman. J Appl Sociol. 2015;26(3):99-116. [Persian]

27. Saleh S, Zahedi Asl M. Correlation of social support with social health of psychiatry veterans wives. Iranian Journal of War and Public Health. 2014;6(5):201-6. [Persian]

28. Nasiry Zarrin Ghabaee N, Talebpour Amir F, Hosseini Velshkolaei MR, Rajabzadeh R. Quality of life and its relationship to the Job stress in among nursing staff in Hospitals of Sari, in 2015. Journal of Nursing Education. 2016;5(2):40-8. [Persian]

29. Ferguson SA, Marras WS. A literature review of low back disorder surveillance measures and risk factors. Clinical Biomechanics. 1997;12(4):211-26.

30. Namdari M, Sharifi T, Tabatabee SS. The effect of job stress on the quality of life of emergency personnel. Journal of management and medical informatics school. 2014;2(1):37-27. [Persian]

31. Khaghanizadeh M, Ebadi A, Sirati NM, Rahmani M. The study of relationship between job stress and quality of work life of nurses in military hospitals. J Mil Med. 2008;10(3):175-84. [Persian]

32. Saraji GN, Dargahi H. Study of quality of work life (QWL). Iranian journal of public health. 2006:8-14. [Persian]

33. Uddin MT, Islam MT, Ullah MO. A study on the quality of nurses of government hospitals in Bangladesh. Proc. Pakistan Acad. Science. 2006;43(2):121-9.

34. Noorbala A. Psychosocial Health and Strategies for improvement. Iranian journal of psychiatry and clinical psychology. 2011;17(2):151-6. [Persian]

35. Hosseini Amin SN, Seyed Mirzaie SM, Adrisi A. Socio-Economic Factors Affecting the Quality of Life of Tehranian Citizens. Soc Welfare Quart. 2017;17(66):223-54. [Persian] 